\title{
Activity of 5-Aminolevulinic Acid Dehydratase Declines during Tomato Fruit Development and Ripening
}

\author{
Marios C. Kyriacou', Gary F. Polking, David J. Hannapel ${ }^{2}$, and Richard J. Gladon ${ }^{2,3}$ \\ Interdepartmental Plant Physiology Major, Department of Horticulture, Iowa State University, \\ Ames, IA 50011-1100
}

Additional index words. chlorophyll biosynthesis, Lycopersicon esculentum

\begin{abstract}
Activity of 5-aminolevulinic acid (ALA) dehydratase [ALAD, (EC 4.2.1.24)] and soluble protein content were determined in 'Rutgers' tomato (Lycopersicon esculentum Mill.) fruit pericarp extracts during development and ripening. ALAD activity in several organs of tomato plant also was determined. Fruit tissue was analyzed at 5-day intervals between days 10 and 60 postanthesis. ALAD activity in fruit tissue declined over time, with the most pronounced decrease occurring between days 10 and 25 . At the mature green stage (day 40), and before the breaker stage (day 45), activity of ALAD had declined to a steady-state minimum, and it remained detectable at residual levels throughout ripening (days 40 to 60 ). Soluble protein content declined less rapidly than did ALAD activity. Immunoblot analysis showed that ALAD protein existed as a doublet of isozymes. One isozyme decreased in abundance, whereas the other isozyme remained constant during development and ripening. ALAD activity was greatest in extracts of chlorophyllous organs (stems, leaves, immature fruit) but only marginally detectable in extracts of nonchlorophyllous organs (roots, overripe fruit). The pH optimum and $\mathrm{K}_{\mathrm{m}}$ for tomato fruit ALAD were similar to those of ALAD isolated from other sources. Abbreviations: ALA, 5-aminolevulinic acid; ALAD, ALA dehydratase; PBG, porphobilinogen; SDS-PAGE, sodium dodecyl sulfate-polyacry lamide gel electrophoresis.
\end{abstract}

One of the first committed enzymes in the chlorophyll biosynthetic pathway is 5-aminolevulinic acid (ALA) dehydratase [ALAD, (EC 4.2. 1.24)]. ALAD catalyzes the condensation of two ALA molecules into the monopyrrole porphobilinogen (PBG) (Jordan and Seehra, 1980). Light regulation of several chlorophyll biosynthesis enzymes, including ALAD, has been documented (Castelfranco and Beale, 1983; Harel, 1978). Previous studies with several plant species have shown that ALAD protein content and enzymatic activity depend upon the type of tissue and the stage of development during light-induced greening. ALAD activity increased during light-induced development of cotyledons of mustard (Sinapis alba L.) seedlings, and phytochrome involvement in ALAD light induction was established (Kasemir and Masoner, 1975). Huault et al. (1987) found parallel increases in ALAD protein content and enzyme activity during chloroplast differentiation in etiolated cotyledons of radish (Raphanus sativus L.). Steady-state levels of ALAD mRNA exhibited little or no change during light-induced greening of etiolated pea (Pisum sativum L.) leaf tissues, and this suggested postranscriptional light regulation of ALAD activity, either at the level of translation or enzyme activation (Boese et al., 1991).

Little research has been conducted on ALAD activity in ripening or senescing tissues, but Naito et al. (1980) showed that ALAD activity decreased continuously with age of primary leaves of bean (Phaseolus vulgaris L.). The purpose of this research was to

Received for publication 5 Dec. 1994. Accepted for publication 5 Apr. 1995. Journal paper no. J-16121 of the Iowa Agriculture and Home Economics Experiment Station, Ames. Project no. 3189. Research taken from a thesis by MCK and a dissertation by GFP in partial fulfillment of the requirements for MS and $\mathrm{PhD}$ degrees in horticulture, respectively. We gratefully acknowledge partial financial support of this research by the Iowa State Univ. Research Foundation. We thank Alain Balangé (Laboratoire de Photobiologie, Faculté des Sciences, Mont Saint Aignan, France) for the generous gift of radish ALAD antibody, and we appreciate critical reviews of this manuscript by W.R. Graves and L.C. Stephens. The cost of publishing this paper was defrayed in part by the payment of page charges. Under postal regulations, this paper therefore must be hereby marked advertisement solely to indicate this fact.

'Current address: P.O. Box 180, Phassouri, Limassol, Cyprus.

${ }^{2}$ Associate professor.

${ }^{3}$ To whom reprint requests should be addressed. measure changes in ALAD activity during tomato fruit development and ripening, so that we may determine whether or not there is a causal relationship between the loss of chlorophyll and events related to the ripening process. In order to provide a context for these data, ALAD activity in extracts of several organs of tomato plants also was measured, enzymological characteristics of ALAD were determined, and presence of ALAD protein was monitored throughout development and ripening.

\section{Materials and Methods}

Chemicals. ALA was purchased from Porphyrin Products (Logan, Utah). Polyvinylpolypyrrolidone, Tris buffer, bovine serum albumin, dithiothreitol, trichloroacetic acid, mercuric chloride, and $p$ dimethylaminobenzaldehyde (Ehrlich's reagent) were obtained from Sigma (St. Louis). All other chemicals were reagent grade.

Plant materials. Lycopersicon esculentum 'Rutgers' tomato plants were grown from seeds in an environmentally controlled greenhouse (20C night, 24C day). Supplementary irradiance of $300 \mu \mathrm{mol} \cdot \mathrm{s}^{-1} \cdot \mathrm{m}^{-2}$ from high-pressure sodium lamps was provided from 0700 to 1900 daily. Uniform transplants were produced in a rockwool-based hydroponic system. Four weeks after sowing, seedlings were transplanted into pots that contained 3 soil : 4 Sphagnum peat: 3 coarse perlite (by volume) for one fruiting cycle (single truss production, McAvoy et al., 1989). Plants were trained to a single stem, and the stem apex was removed above the first leaf that followed the first inflorescence. Seedlings were maintained with $10.7 \mathrm{~mol} \mathrm{~N} / \mathrm{m}^{3}$ from Cal-Mag Peters Excel nutrient solution (15-2.2-12.45; The Scotts Co., Marietta, Ga.). Flowers were pollinated and tagged at anthesis (Lyons and Pratt, 1964), and three fruit were produced on each plant. For ALAD assays, stages of fruit development were 1) cell division from 0 to 20 days; 2) cell expansion from 20 to 40 days; 3 ) mature green at 40 days; (4) breaker to turning at 45 days; 5) light pink at 50 days; 6) pink at 55 days; 7) ripe at 60 days; and 8) overripe at 65 days (Martinet al., 1979). Fruit were harvested at each 5-day interval from 10 to 65 days postanthesis. Root, stem, and leaf tissues were obtained from seedlings that were 4 weeks old and not used for fruit production. For immunoblot analysis, fruit were harvested at 10, 15,25,35,45, 
and 55 days postanthesis, frozen in liquid $\mathrm{N}_{2}$, and stored at -80C. Stages of fruit development were similar to those for fruit used in the enzyme assays, with the exception that fruit 55 days postanthesis were fully ripe.

Enzyme extraction. A core of tissue $1 \mathrm{~cm}$ in diameter was removed from the blossom end axis of each fruit with a stainlesssteel cork borer, and $1 \mathrm{~g}$ of tissue (including the epidermis) was used for extraction. Similarly, $1 \mathrm{~g}$ of root, stem (basal part of epicotyl), or leaf (laminae of first leaf pair) tissue was used. The tissue was ground to a fine powder under liquid $\mathrm{N}_{2}$ in a mortar. Immediately after grinding, $1 \mathrm{~g}$ of polyvinylpolypyrrolidone was mixed with the powdered tissue to prevent phenolic oxidation. After addition of $5 \mathrm{ml}$ of $25 \mathrm{~mm}$ Tris- $\mathrm{HCl}$ buffer $(\mathrm{pH} \mathrm{7.6)}$ that contained $4 \mathrm{~mm}$ dithiothreitol, the homogenate was filtered through four layers of cheesecloth and centrifuged at $10,000 \times g$ for $10 \mathrm{~min}$. The pellet was discarded, and the supernatant was used as the enzyme source. Soluble protein content of the extract was determined by the Bradford (1976) method.

Enzyme assay. ALAD activity was measured according to the method of Smith and Griffiths (1993) modified for use on tomato tissues. Buffer systems based on sodium phosphate, HEPES, carbonate-bicarbonate, borate-sodium borate, and Tris- $\mathrm{HCl}$ were tested for use in these assays. The standard reaction mixture (total volume $300 \mu \mathrm{l}$ ) was prepared in a microcentrifuge tube on ice, and it contained $113 \mu \mathrm{l}$ of extract, $50 \mathrm{~mm}$ Tris- $\mathrm{HCl}$ buffer $(\mathrm{pH} \mathrm{8.7,}$ unless otherwise mentioned), $10 \mathrm{~mm}$ ALA (unless otherwise mentioned), and $6 \mathrm{mM} \mathrm{MgCl}_{2}$. The reaction was initiated by addition of the extract at time zero. After $1 \mathrm{~h}$ at $37 \mathrm{C}$ with gentle shaking $(150 \mathrm{rpm})$, the reaction was stopped by addition of $300 \mu \mathrm{l}$ of $10 \%$ trichloroacetic acid and $2.7 \% \mathrm{HgCl}_{2}(\mathrm{w} / \mathrm{v})$. The mixtures were microcentrifuged at $16,000 \times g(14,000 \mathrm{rpm})$ for $8 \mathrm{~min}$ to precipitate proteins, and $500 \mu \mathrm{l}$ of supernatant was mixed $1: 1$ with modified Ehrlich's reagent (Mauzerall and Granick, 1956). After 15 rein, absorbance of the mixture at $553 \mathrm{~nm}$ was determined against a reaction mixture blank that did not contain ALA. PBG concentration was calculated by using a molar extinction coefficient of $6.2 \times 10^{4}$ per M per cm (Kaul and Sabharwal, 1974). The effect of $\mathrm{pH}$ on ALAD activity was determined by varying the
$\mathrm{pH}$ of the Tris- $\mathrm{HCl}$ reaction buffer. Initial velocity at increasing substrate concentrations was determined, and $\mathrm{V}_{\max }$ and $\mathrm{K}_{\mathrm{m}}$ values were obtained from an Eadie-Hofstee plot.

Immunoblot analysis. Protein was isolated by grinding $1 \mathrm{~g}$ of tissue in $2 \mathrm{ml}$ of grinding buffer $\left(25 \mathrm{mM} \mathrm{NaH}_{2} \mathrm{PO}_{4}, \mathrm{pH} 7.0,0.1 \%\right.$ diethyldithiocarbamate, and $\left.0.1 \% \quad \mathrm{NaHSO}_{3}\right)$. The extract was centrifuged at $16,000 \times \mathrm{g}$ for $1 \mathrm{rein}$, and $50 \mu \mathrm{l}$ of supernatant was added to $50 \mu \mathrm{l}$ of extraction buffer ( $25 \mathrm{~mm}$ Tris-HCl, $\mathrm{pH} 6.8,1.6 \%$ SDS, and 2.6\% $\beta$ - mercaptoethanol). The mixture was boiled for 1.5 rein, and $10 \mu \mathrm{l}$ of loading buffer $(0.05 \%$ bromphenol blue, 25

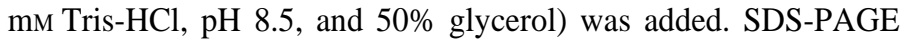
(12.5\% acrylamide) that used $20 \mu \mathrm{l}$ of each sample was performed, and proteins were transferred to a nitrocellulose membrane essentially as described by Towbin et al. (1979). Immunoblotting and staining were carried out as described by Hannapel ( 1990) by using a 1:4000 dilution of the $\mathrm{BS}_{2}$ antibody to radish ALAD (Tchuinmogné et al., 1992) isolated from rabbit. The second antibody was goat anti-rabbit IgG-horseradish peroxidase conjugate (BioRad Laboratories, Inc., Richmond, Calif.).

Experimental design. Replicates of fruit of the same physiological class were obtained from the entire plant population. ALAD activity and protein content determinations during fruit development and ripening were done in a randomized block design of eight blocks. Each block consisted of 11 fruit, with one fruit for each 5-day increment from 10 to 60 days. Determination of organspecific ALAD activity was done by using a completely randomized design with eight replications. Replicates were single fruit or single samples of root, stem, or leaf tissues. The effects of $\mathrm{pH}$ and ALA concentration on ALAD activity were determined according to randomized block designs with eight blocks. Extract from one fruit was used in each block. Fruit 10 days postanthesis were used for studying the effect of ALA concentration, and fruit 15 days postanthesis were used for studying the effect of $\mathrm{pH}$. The test for presence of an enzyme inhibitor was done by using a randomized block design with four blocks. Each block included one fruit at 20 and 65 days postanthesis and their combined $(1: 1)$ extracts. For statistical analysis, we used software package release 6.06 from SAS Institute (Cary, N.C.).

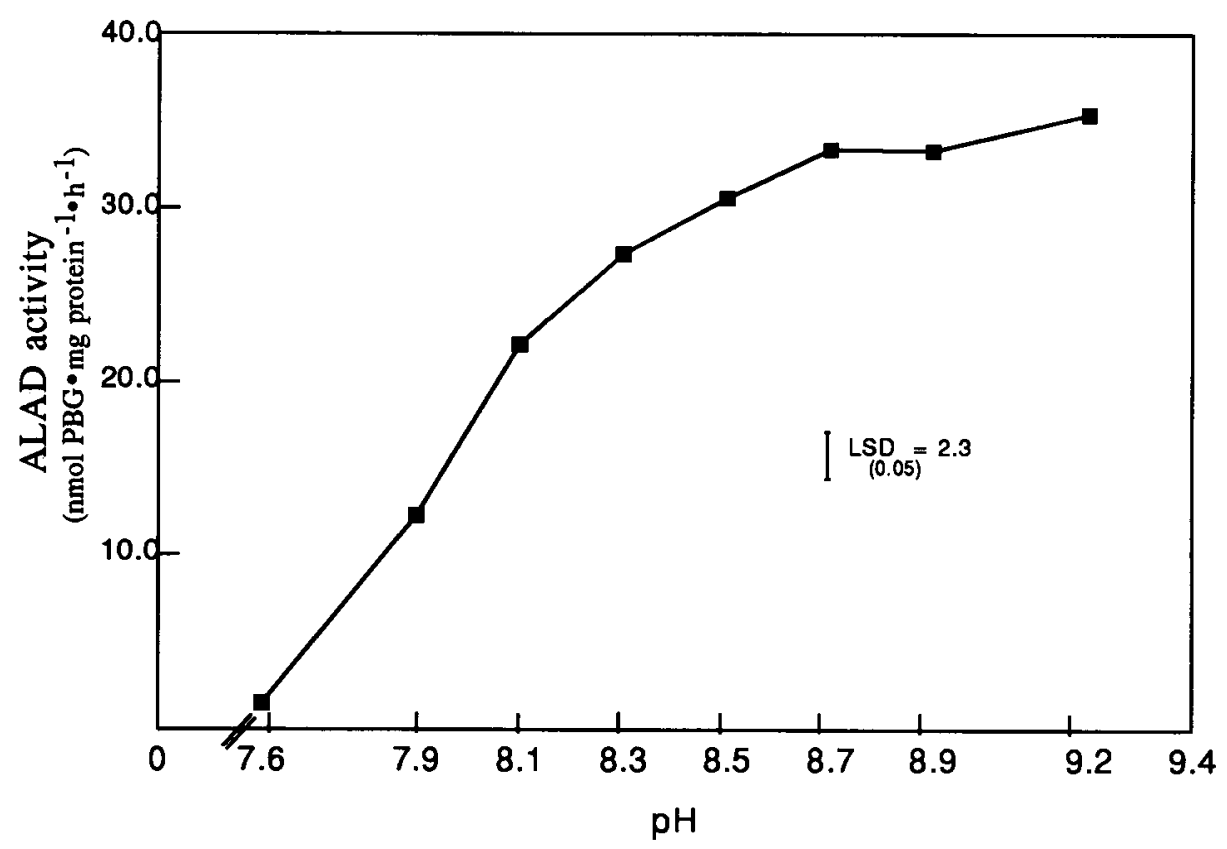

Fig. 1. Effect of $\mathrm{pH}$ on ALAD activity. Enzyme was extracted from fruit 15 days postanthesis and $50 \mathrm{~mm}$ Tris- $\mathrm{HCl}$ buffer and 10 mm ALA were used. Each point is a mean of eight replicates (Fisher's LSD, $P=0.05$ ). 


\section{Results and Discussion}

ALAD activity in several buffer systems (sodium phosphate, HEPES, carbonate-bicarbonate, borate-sodium borate, and Tris$\mathrm{HCl}$ ) was determined, and the greatest activity was observed in Tris- $\mathrm{HCl}\left(\mathrm{pK}_{\mathrm{a}}^{\prime}\right.$ at $\left.20 \mathrm{C}=8.3\right)$ (data not presented). ALAD activity in Tris- $\mathrm{HCl}$ buffer increased rapidly between $\mathrm{pH} 7.6$ and 8.5, and it reached a plateau near $\mathrm{pH} 8.7$ (Fig. 1). Therefore, all subsequent assays were conducted at $\mathrm{pH}$ 8.7. ALAD exhibited typical Michaelis-Menten kinetics (Fig. 2). A $\mathrm{K}_{\mathrm{m}}$ of $0.74 \mathrm{~mm}$ for ALA and a $\mathrm{V}_{\max }$ of $49.4 \mathrm{nmol} \mathrm{PBG} / \mathrm{mg}$ protein per $\mathrm{h}$ were obtained from an EadieHofstee plot of $\mathrm{V}$ against V/S. The saturating ALA concentration of $10 \mathrm{~mm}$ was used in all subsequent analyses. During time-course studies of ALAD activity, the rate of reaction was linear for 80 rein; therefore, the incubation period was restricted to $1 \mathrm{~h}$ (data not presented). Similar results have been reported by other researchers. Schneider (1970) found a broad $\mathrm{pH}$ optimum of 7.9 to 9.0 for ALAD from crude leaf extract of spinach (Spinacea oleracea L.) and observed a $\mathrm{pH}$ optimum of 8.2 for the highly purified enzyme. A broad $\mathrm{pH}$ optimum of 9.2 to 9.5 has been reported for ALAD from crude extracts of green callus of tobacco (Nicotiana tabacum L.) (Kaul and Sabharwal, 1974). Nandi and Waygood (1967) measured a $\mathrm{K}_{\mathrm{m}}$ of $1.0 \mathrm{~mm}$ for ALA in leaves of wheat (Triticum aestivum L.), and Kaul and Sabharwal (1974) reported a Km of $0.46 \mathrm{~mm}$ for ALA.

Between days 10 and 40 postanthesis, ALAD activity and soluble protein content (Fig. 3) decreased rapidly. During ripening, days 40 to 60 postanthesis, soluble protein content declined slightly and ALAD activity remained detectable at residual levels. In an analysis separate from that shown in Fig. 3, ALAD activity from fruit 20 days postanthesis was $44.8 \pm 3.6 \mathrm{nmol} \mathrm{PBG} / \mathrm{ml}$ extract per $\mathrm{h}$, whereas activity from fruit 65 days postanthesis was $1.8 \pm 0.7 \mathrm{nmol} \mathrm{PBG} / \mathrm{ml}$ extract per $\mathrm{h}$. When extracts from each of these ages of fruit were mixed in equal volumes, the resultant activity was $21.5 \pm 2.4 \mathrm{nmol} \mathrm{PBG} / \mathrm{ml}$ extract per $\mathrm{h}$, which was $92 \%$ of the expected additive activity. Extracts from roots and from fruit 65 days postanthesis yielded residual levels of ALAD activity (Table 1). Greatest ALAD activity was observed in leaf extracts, whereas fruit 15 days postanthesis yielded an ALAD activity almost twice that found in stem extracts.

The observed rapid decline in ALAD activity between days 10 and 25 of fruit development indicates that developmental regulation of ALAD activity and chlorophyll biosynthesis takes place at the initial stages of fruit development, during the period of cell division and the beginning of cell enlargement. Inactivation of many photosynthesis-specific genes in tomato pericarp tissue takes place in the presence of light within two weeks after pollination (Piechulla et al., 1987). Naito et al. (1980) showed that chloroplast replication and enlargement coincide with chlorophyll synthesis (expressed as ALA synthesis capacity and ALAD activity) in intact bean leaves during ageing. Naito et al. (1980) also showed that ALAD activity decreased continuously with leaf age but was still detectable at the onset of senescence. These findings support our data that show ALAD activity decreasing to a minimum (about day 40) before the fruit reaches the breaker stage (about day 45) (Fig. 3). In contrast, the activities of other ripeningrelated enzymes, such as 1-aminocyclopropane- 1-carboxylic acid synthase and polygalacturonase (Su et al., 1984) and acid invertase (Sato et al., 1993), are marked by large increases after the initiation of ripening. Thus, our results indicate that a decline in chlorophyll synthesis capacity, not just increased chlorophyll breakdown, precedes the visual transition in fruit pigmentation.

The residual ALAD activity maintained after fruit maturation (days 40 to 60, Fig. 3) and into senescence (day 65, Table 1 ) might be explained by the constant demand for pyrrolic compounds, particularly heme for respiratory cytochromes, peroxidases, and

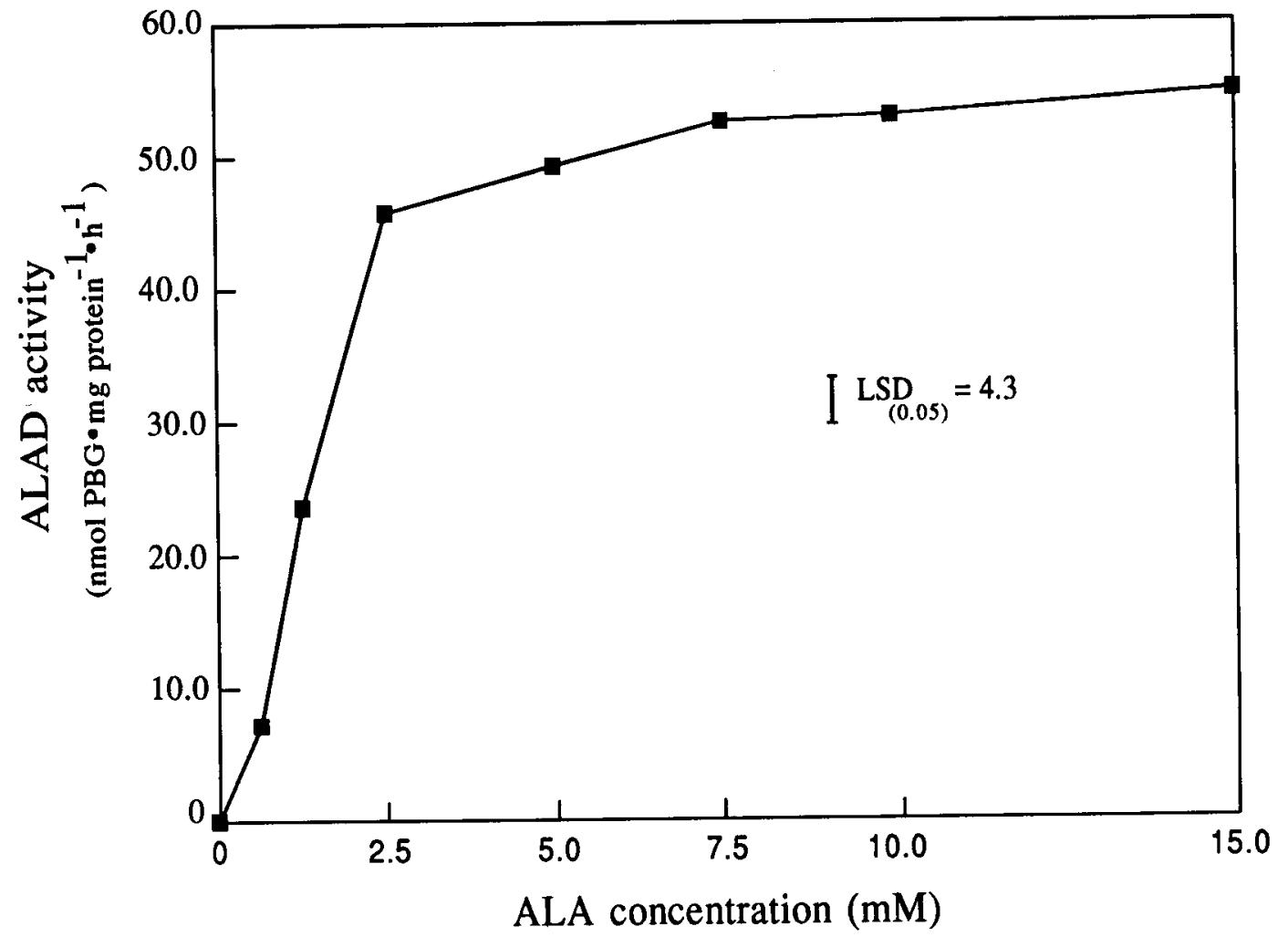

Fig. 2. Effect of ALA concentration on ALAD activity at pH 8.7. Enzyme was extracted from fruit 10 days postanthesis. Each point is a mean of eight replicates (Fisher's LSD, $P=0.05$ ). 


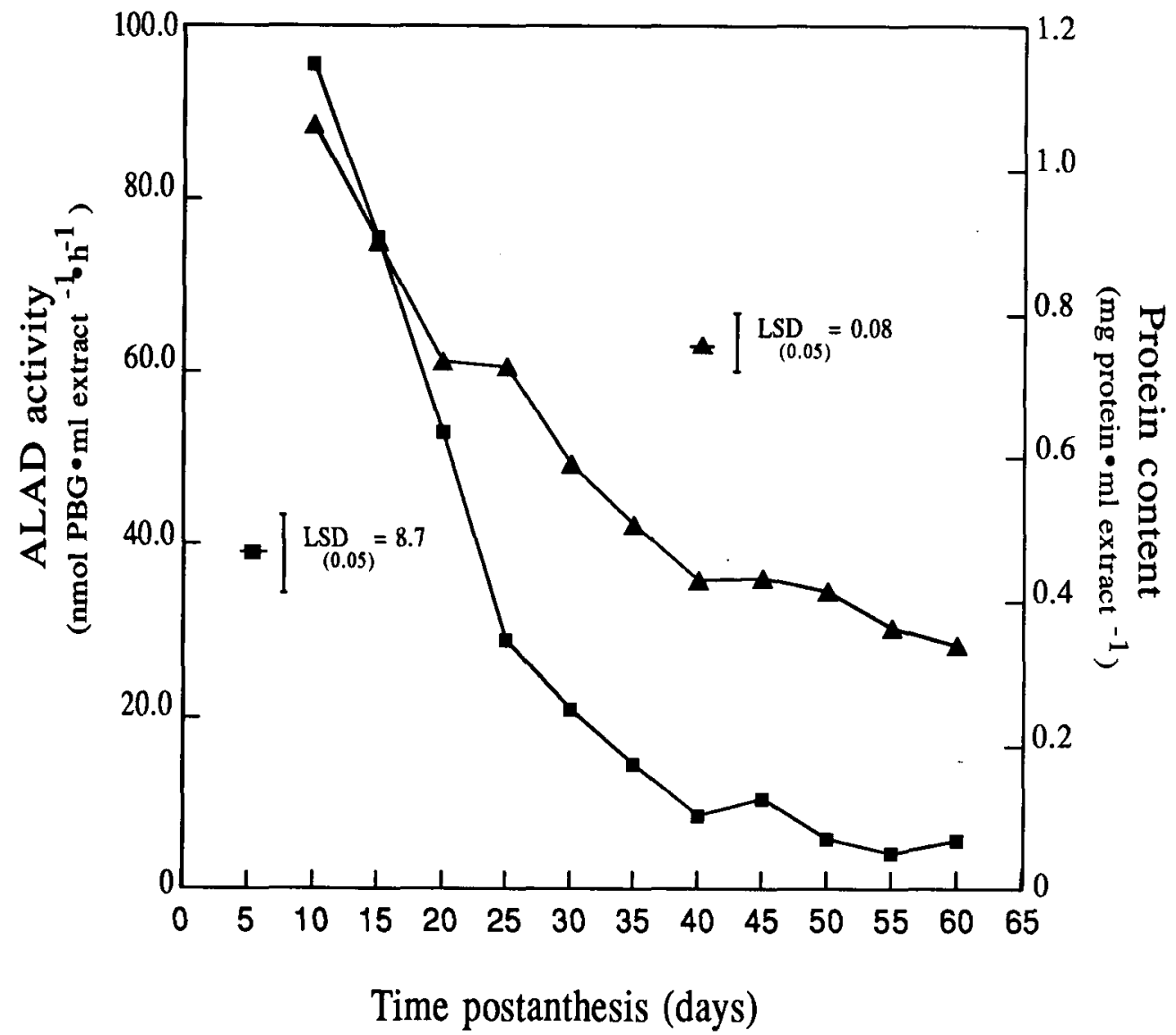

Fig. 3. ALAD activity ( $\boldsymbol{\square}$ ) and soluble protein content ( $\boldsymbol{\Delta}$ ) of tomato fruit pericarp tissue during development and ripening. Each point is a mean of eight replicates (Fisher's LSD, $P=0.05$ ),

other oxidative enzymes (Werck-Reichhart et al., 1988). Naito et al. (1980) also detected ALAD activity in intact bean leaves at the onset of senescence. It seems unlikely that the decline in ALAD activity in older fruit is due to the appearance of a soluble enzyme inhibitor as ripening events commence. Activity in a 1:1 mixture of extracts from fruit 20 and 65 days postanthesis was nearly additive. Presence of a soluble enzyme inhibitor in ripe fruit would have resulted in low ALAD activity in mixed extracts, and this was not the case. Nevertheless, the presence of abound inhibitor, which could have been removed with cellular debris during extraction, cannot be excluded on the basis of our procedures and results. The marked decline in ALAD activity that we observed probably was not caused by an inhibitor of this type because ALAD does not seem to be a membrane-associated enzyme (Smith, 1988; Boese et al., 199 1). Soluble protein content and ALAD activity declined concurrently during tomato fruit development and ripening (Fig. 3). This suggests that the decrease in ALAD activity may have been concomitant with and caused by a decrease in the amount of enzyme in the pericarp tissue, rather than some other factor(s) such as decreased ALAD gene expression or the appearance of an inhibitor of ALAD.

Immunoblot analysis showed that radish ALAD antibody reacted with protein that had an approximate mass of $41 \mathrm{kD}$ in fruit tissue, and there is a doublet present (Fig. 4, see arrow). Radish ALAD antibody also reacted with a protein of about $52 \mathrm{kD}$ in tomato fruit tissue (Fig. 4) and proteins in tomato stem, leaf, and root tissue (data not presented). The bands at about $41 \mathrm{kD}$ corresponded to the observed mass of radish ALAD (40kD; Tchuinmogné et al., 1992) and to the predicted mass of mature ALAD of tomato (41.7 kD; Polking et al., 1995) and spinach (40.1 kD; Schaumberg et al., 1992). The presence of this doublet at about $41 \mathrm{kD}$ complicates the interpretation of our results. The higher molecular weight band generally decreased throughout fruit development and ripening, whereas the intensity of the lower molecular weight band remained essentially constant (Fig. 4). These two bands may represent ALAD isozymes that differ in their gene expression pattern or their levels of posttranslational processing. Thus, the observed decrease in ALAD activity between days 10 and 40 of fruit development (Fig. 3) could be due either to decreased abundance of the higher molecular weight isozyme or decreased activity of the lower molecular weight isozyme. Future work should be directed toward elucidating which of these possibilities is correct. The $52 \mathrm{kD}$ protein is of a size that could correspond approximately to the predicted size of the full-length polypeptide ( $46.9 \mathrm{kD})$, and it may represent the unprocessed form of ALAD. However, it is more likely that the signal observed may represent cross-reactivity

Table 1. ALAD activity in extracts of root, stem, and leaf tissues from seedlings 4 weeks old, and pericarp tissue from immature fruit ( 15 days) and overripe fruit ( 65 days $)^{2}$.

\begin{tabular}{lr}
\hline \hline Enzyme source & $\begin{array}{c}\text { ALAD activity } \\
(\mathrm{nmol} \mathrm{PBG} / \mathrm{ml} \text { extract/h) }\end{array}$ \\
\hline Root & $9.8 \mathrm{~d}$ \\
Stem & $32.9 \mathrm{c}$ \\
Leaf & $137.6 \mathrm{a}$ \\
Fruit (15 days) & $61.9 \mathrm{~b}$ \\
Fruit (65 days) & $7.7 \mathrm{~d}$
\end{tabular}

${ }^{2}$ Means followed by different letters are different according to Fisher's LSD $(P=0.05)$. Each mean represents eight replications. 


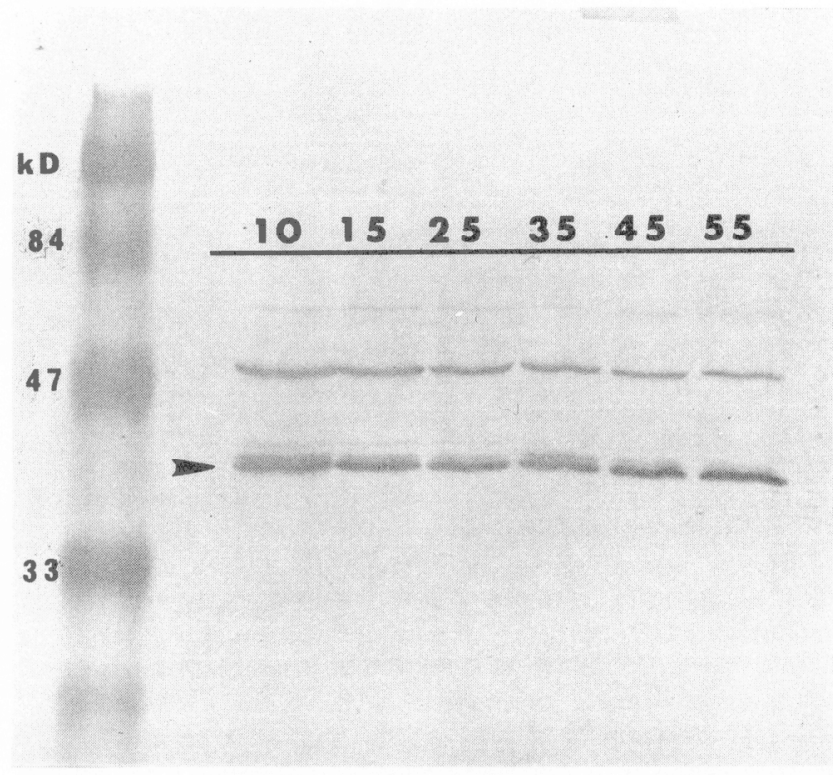

Fig. 4. Immunoblot analysis using radish ALAD antibody against total protein extracted from tomato fruit pericarp tissue harvested 10, 15, 25, 35,45, and 55 days postanthesis. Twenty microliters of extract were added per lane. Arrow indicates approximate predicted size of mature ALAD protein.

with another tomato protein because it is larger than the "fulllength polypeptide."

ALAD activity was greater in chlorophyllous organs (stems, leaves, immature fruit) than in nonchlorophyllous organs (roots, ripe fruit) (Table 1). This may reflect the possible predominance of the heme branch of the porphyrin pathway in roots and ripe fruit, whereas both the heme and chlorophyll branches of the pathway may be active in stems, leaves, and immature fruit. As expected, ALAD activity was greatest in photosynthetically active tissues. ALAD activity in stem extracts was about half that in young fruit (15 days), in which photosynthetic activity reportedly is important despite the influx of photosynthates from leaves (Piechulla et al., 1987). The minimal ALAD activity in root extracts, which was comparable to that of overripe fruit (65 days), is in contrast to the relatively high levels of steady-state ALAD mRNA found in root tissues of 'Rutgers' tomato seedlings (Polking et al., 1995), the level of ALAD protein in ripe fruit (Fig. 4), and the prominent level of ALAD protein in roots (data not presented). These results also suggest that regulation of ALAD activity in nonchlorophyllous organs occurs posttranslationally.

The decreasing level of ALAD activity during tomato fruit development and ripening in the presence of light indicates that, in addition to regulation by light (Kasemir and Masoner, 1975; Huault et al., 1987; Boese et al., 1991), a developmental regulation mechanism may be superimposed on chlorophyll biosynthesis enzymes. Such regulation of chlorophyll biosynthesis seems to take place at the initial stages of tomato fruit development and before the visible transition in fruit pigmentation.

\section{Literature Cited}

Boese, Q.G., A.J. Spano, Li Jianming, and M.P. Timko. 1991. Aminolevulinic acid dehydratase in pea (Pisum sativum L.). J. Biol. Chem. 226:1706017066.

Bradford, M.M. 1976. A rapid and sensitive method for the quantitation of microgram quantities of protein utilizing the principle of protein-dye binding. Anal. Biochem. 72:248-254.

Castelfranco, P.A. and S.I. Beale. 1983. Chlorophyll biosynthesis Recent advances and areas of current interest. Annu. Rev. Plant Physiol. 34241-278.
Hannapel, D.J. 1990. Differential expression of potato tuber protein genes. Plant Physiol. 94:919-925.

Harel, E. 1978. Chlorophyll biosynthesis and its control. Prog. Phytochem. 5:127-180.

Huault, C., A. Aoues, and P. Colin. 1987. Immunochemical study of 8aminolevulinate dehydratase in etiolated radish cotyledons. Plant Physiol. Biochem. 25:723-728.

Jordan, P.M. and J.S. Seehra. 1980. Mechanism of action of 5-aminolevulinic acid dehydratase: Stepwise order of addition of the two molecules of 5aminolevulinic acid in the enzyrnic synthesis of porphobilinogen. J. Chem. Soc. Chem. Comm. 240-242.

Kasernir, H. and M. Masoner. 1975. Control of chlorophyll synthesis by phytochrome. II. The effect of phytochrome on aminolevulinate dehydratase in mustard seedlings. Planta 126:119-126.

Kaul, K and P.S. Sabharwal. 1974. Kinetin-induced changes in $\delta$-aminolevulinic acid dehydratase of tobacco callus. Plant Physiol. 54:644-648.

Lyons, J.M. and H.K. Pratt. 1964. Effect of stage of maturity and ethylene treatment on respiration and ripening of tomato fruits. Proc. Amer. Soc. Hort. Sci. 84:491-500.

Martin, B. A., J.A. Gauger, and N.E. Tolbert. 1979. Changes in activity of ribulose-1,5-bisphosphate carboxylase/oxygenase and three peroxisomal enzymes during tomato fruit development and ripening. Plant Physiol. 63:486-489.

Mauzerall, D. and S. Granick. 1956. Theoccurrence and determination of $\delta-$ aminolevulinic acid and porphobilinogen in urine. J. Biol. Chem. 219435-445.

McAvoy, R.J., H.W. Janes, G.A. Giacomelli, and M.S. Giniger. 1989. Validation of a computer model for a single-truss tomato cropping system. J. Amer. Soc. Hort. Sci. 114:746-750.

Naito, K., T. Ebato, Y. Endo, and S. Shimizu. 1980. Effect of benzyladenine on $\delta$-aminolevulinic acid dehydratase: Differential responses to benzyladenine according to leaf age. Z. Pflanzenphysiol. 96:95-102.

Nandi, D.L. and E.R. Waygood. 1967. Biosynthesis of porphyrins in wheat leaves. II. 5-aminolevulinate hydrolase. Can. J. Biochem. 45:327-336.

Piechulla, B., R.E. Glick, R.E. Bahl, H. Melis, and W. Gruissem. 1987. Changes in photosynthetic capacity and photosynthetic protein pattern during tomato fruit ripening. Plant Physiol. 84:911-917.

Polking, G.F., D.J. Hannapel, and R.J. Gladon. 1995. Characterization of a cDNA encoding 5-aminolevulinic acid dehydratase in tomato (Lycopersicon esculentum Mill.). Plant Cell Rpt. 14:366-369.

Sato, T., T. Iwatsubo, M. Takahashi, H.Nakagawa, N. Ogura and H.Mori. 1993. Intercellular localization of acid invertase in tomato fruit and molecular cloning of a cDNA for the enzyme. Plant Cell Physiol. 34263-269.

Schaumburg, A., H.A.W. Schneider-Poetsch, and C. Eckerskom. 1992. Characterization of plastid 5-aminolevulinate dehydratase (ALAD;EC 4.2. 1.24) from spinach (Spinacia oleracea $\mathrm{L}$.) by sequencing and comparison with non-plant enzymes. Z. Naturforsch. 47c:77-84.

Schneider, H.A.W. 1970. Purification and properties of $\delta$-aminolevulinate dehydratase from spinach (Spinacea oleracea) leaves. Z. Planzenphysiol. 62:328-342.

Smith, A.G. 1988. Subcellular localization of two porphyrin-synthesis enzymes in Pisum sativum (pea) and Arum (cuckoo-pint) species. Biochem. J. 249:423-428.

Smith, A.G. and W.T. Griffiths. 1993. Enzymes of chlorophyll and heme biosynthesis, p. 299-343. In: Methods in plant biochemistry. vol. 9. Academic Press. New York.

Su, L., T. McKeon, D. Grierson, M. Cantwell, and S.F. Yang. 1984. Development of 1-aminocyclopropane-1-carboxylic acid synthase and polygalacturonase activities during the maturation and ripening of tomato fruit. HortScience 19:576-578.

Tchuinrnogné S.T., P. Bruyant and A.P. Balangé. 1992. Immunological characterization of two 5-aminolevolinate dehydratases in radish leaves. Plant Physiol. Biochem. 30:255-261.

Towbin, H., T. Staehelin, and J. Gordon. 1979. Electrophoretic transfer of proteins from polyacrylamide gels to nitrocellulose sheets: Procedure and some applications. Proc. Natl. Acad. Sci. USA 76:4350-4354.

Werck-Reichhart, D., O.T.G. Jones, and F. Durst. 1988. Haem synthesis during cytochrome P-450 induction in higher plants. 5-Aminolevulinic acid synthesis through a five-carbon pathway in Helianthus tuberosus tuber tissues aged in the dark. Biochem. J. 249:473-480. 